\title{
Sestina dalam sudut pandang Estetika Monroe C. Berdsley
}

\author{
I Wayan M. Dhamma Narayanasandhy \\ Wayandhamma11@gmail.com
}

\begin{abstract}
The model song is a song that is used as a medium in achieving theme based learning. The problem in the process of creating songs is the difference in students' musical abilities between the background of music education and students in the PG-PAUD Study Program. This study aims to describe the optimization of the learning process of song copyright for early childhood learning. This study uses a qualitative approach. The subjects in this study were level II students in class $A, B, C$, and D, totaling 59 students. This research was conducted in the even semester of the 2015/2016 academic year, with data collection techniques in the form of interviews, observation, and documentation studies. The results of the study concluded that the way to optimize the creation of "Model Song" for early childhood is through making a synopsis, implementing collaborative discussion methods, appreciation, and documenting songs in the form of CDs and books. With the right method in optimizing the learning process, it can improve the quality of songs created by students.
\end{abstract}

Keywords: Optimization, Model Song, Early Childhood.

\begin{abstract}
Abstrak
Setiap karya musik yang dinyanyikan, biasanya memiliki sebuah lirik yang ikut andil di dalamnya. Kebanyakan, penciptaan sebuah lirik terinspirasi dari sebuah puisi. Banyak sekali jenis-jenis puisi di dunia, salah satunya adalah puisi Sestina. Penelitian ini berjudul "Sestina dalam sudut pandang Estetika Monroe C. Berdsley". puisi Sestina adalah salah satu puisi kuno yang tidak memiliki unsur rima tetapi memiliki algoritma repetisi yang disebut circular of sestina. Dalam sebuah karya seni, selalu memiliki suatu estetika yang terkandung di dalamnya. Dengan meninjau lebih dalam tentang estetika, penelitian ini berfokus pada estetika yang dikemukakan oleh Monroe C. Berdsley. Tujuan penelitian ini adalah untuk mengetahui jenis karya sastra sestina dalam sudut pandang teori estetika dari Monroe C. Berdsley. Penelitian ini bersifat deskriptif dengan sebuah pendekatan yang menjurus pada studi kepustakaan. Hasil dari penelitian ini adalah menjelaskan tentang ketiga unsur Intensity, Complexity, dan Unity yang terdapat dalam suatu karya sastra Sestina dengan menggunakan contoh karya puisi Sestina yang diciptakan oleh Elizabeth Bishop..
\end{abstract}

Kata kunci: Sestina, Estetika, Musik

\section{Pengantar}

Pada industri musik saat ini, "Lagu" merupakan salah satu karya seni paling populer yang dapat diterima oleh masyarakat. Cerminan emosi atau isu yang ada di sekitar masyarakat dapat tergambarkan dengan jelas dalam setiap potongan lagu. Senang, sedih, cinta, persahabatan, agama bahkan politik adalah contoh topik yang dapat diangkat oleh sebuah lagu hingga membuat para pendengar terhasut olehnya. Ekspresiekspresi yang tertuang di dalamnya, juga memiliki kekuatan tersendiri yang bahkan bisa menyatukan atau memisahkan suatu masyarakat dunia.

Lagu adalah karya musik yang biasanya dimainkan oleh suara manusia dengan melodi dan pola repetisi yang beragam. Dalam pengertian yang luas, lagu juga bisa merujuk pada suatu karya musik yang hanya dimainkan oleh instrumen musik saja atau 
biasa disebut "instrumental music". Lagu dapat dinyanyikan dengan cara solo, duet, trio, vocal group bahkan kelompok besar (choir). Sebagai suatu bentuk karya seni, lagu juga dapat dibawakan dengan sangat fleksibel : pertama, dapat dibawakan dengan iringan instrumen musik; kedua, dapat dibawakan tanpa iringan instrumen musik (acapella).

Dilihat dari sudut pandang penyajiannya, lagu yang diperuntukkan untuk solo singer atau duet bisa diiringi oleh background singer / backing vocal yang memainkan nada unison ataupun harmoni dari main vocal nya. Vocal group juga memiliki pembagian sebagai main vocal dan backing vocal yang diidentikan dengan suara satu, dua, tiga dan seterusnya. Bahkan untuk choir juga bisa diberikan pembagian backing vocal, hanya saja berbeda dari vocal group yang berfokus pada suara satu, dua, dst, tetapi lebih kepada pembagian range suara sopran, alto, tenor dan bass.

Disaat suatu kelompok atau seorang individu menampilkan suatu Lagu, maka hal tersebut biasanya tidak akan mungkin terlepas dari skena genre. Terdapat banyak sekali genre yang ada di dunia. dari ujung ke ujung, dari Amerika hingga Australia. Kelima benua yang diketahui oleh masyarakat luas telah memberikan kontribusi yang sangat banyak terhadap perkembangan genre-genre musik. Musik klasik, jazz, reggae, dangdut, ska, rock, country, polka, hip-hop, EDM, religious, sacred, traditional, dll, merupakan suatu hasil karya musik yang telah memiliki ciri khas tersendiri.

Jika ditelisik lebih dalam, "lagu" merupakan gabungan antara lirik dan melodi yang disatukan dalam suatu kesatuan. Melodi yang menghiasi lirik adalah suatu nada-nada yang dapat memikat para pendengar. Melodi juga dapat membuat ciri khas dari sebuah lagu. Sedangkan lirik adalah sebuah sastra yang dipaparkan oleh lagu agar dapat dimengerti oleh para pendengar. Dimensi lirik menjadi hal yang sangat krusial dalam sebuah lagu. Bukan rahasia umum lagi, jika lirik sangat mempengaruhi makna / arti suatu lagu.

Lirik berakar dari sebuah puisi maupun prosa yang ditulis oleh seorang songwriter. Mayoritas dalam pembuatan sebuah lagu, selalu mengambil struktur puisi yang memiliki rima seperti abab, aabb, abba, aabbcc, dan sebagainya. Terdapat banyak sekali jenis puisi yang tersebar penjuru bumi ini. Macam-macam puisi lokal seperti gurindam, syair, karmina, balada, pantun, dsb memiliki ciri berima. Begitu juga dengan jenis puisi yang terdapat di mancanegara seperti elegy, haiku, ballad, epic, sonnet, villanelle, limerick, dan seterusnya juga memiliki ciri berima. Namun dari semua puisi berima yang telah disebutkan diatas, terdapat salah satu puisi yang tidak memiliki rima yaitu Sestina.

Pada abad ke-12 di Perancis, Sestina adalah salah satu karya seni sastra yang muncul. Sebuah puisi yang selalu dikaitkan oleh seorang troubadour bernama Arnaut Daniel. Secara etimologi, troubadour berasal dari bahasa perancis yang artinya "penyair" atau bisa dikaitkan dengan komposer puisi ataupun penyanyi. Pada zaman pertengahan tinggi di Eropa, Sestina termasuk karya sastra yang lumayan digemari oleh para troubadour dan juga dijadikan suatu lirik dalam sebuah lagu. Ketertarikan masyarakat pada jenis puisi Sestina ini adalah tidak berima atau bisa dikatakan memiliki sebuah algoritma yang diterapkan pada suatu repetisi.

Ciri puisi Sestina ialah memiliki 6 stanza yang pada setiap stanza-nya berisi 6 baris kalimat. Pada akhir stanza, terdapat sebuah stanza tambahan yang terdiri dari 3 baris kalimat yang juga dapat disebut tercet. Daya tarik Sestina ini terletak pada kenyataan bahwa kata-kata kunci dan frasa tertentu diulang dalam setiap bait, yang membantu 
membangun gambaran ganda. Bentuk sestina membutuhkan ketaatan pada aturannya yang ketat. Meskipun ini adalah bentuk bait yang kompleks, ia mencapai efek luar biasa karena pengulangan kata-kata yang rumit, yang disebut "pengulangan leksikal." Oleh karena itu, tidak bergantung pada pengukur atau rima saja. Terlepas dari menarik perhatian pada strukturnya, pengulangan leksikal ini menciptakan irama dalam puisi, membawa harmoni di antara berbagai bait, meningkatkan materi, membuat gagasan itu tetap hidup di benak pembaca, dan melibatkannya. Oleh karena itu, fungsi dasar sestina adalah untuk memfokuskan ide.

Aksentuasinya adalah pada perubahan posisi kata-kata akhir, sehingga membentuk suatu pola tertentu. Dalam puisi Sestina, teknik yang dibakukan ini disebut "Circular of Sestina". Teknik ini adalah sebuah repetisi yang terstruktur. Repetisi yang hanya diberikan pada akhir kata pada setiap kalimat dalam setiap stanza.

Tabel 1.

\begin{tabular}{|c|l|l|l|l|l|}
\hline Stanza 1 & Stanza 2 & Stanza 3 & Stanza 4 & Stanza 5 & Stanza 6 \\
\hline 1 A & 6 F & 3 C & 5 E & 4 D & 2 B \\
\hline 2 B & 1 A & 6 F & 3 C & $5 \mathrm{E}$ & $4 \mathrm{D}$ \\
\hline 3 C & 5 E & 4 D & 2 B & 1 A & $6 \mathrm{~F}$ \\
\hline 4 D & 2 B & 1 A & 6 F & $3 \mathrm{C}$ & $5 \mathrm{E}$ \\
\hline 5 E & 4 D & 2 B & 1 A & $6 \mathrm{~F}$ & 3 C \\
\hline 6 F & 3 C & 5 E & 4 D & 2 B & 1 A \\
\hline
\end{tabular}

Tabel di atas adalah gambaran algoritma yang disuguhkan oleh jenis puisi sestina. Kata akhir pada setiap kalimat akan diulang kembali pada kalimat di stanza berikutnya tetapi dengan posisi kalimat yang berbeda. Seperti contoh, kata akhir pada kalimat pertama pada stanza pertama, akan diulang di stanza kedua pada kalimat kedua. Algoritma inilah yang membuat puisi sestina memiliki nilai keindahan tersendiri.

Keindahan yang dipaparkan dapat bergantung pada siapa yang menikmatinya. Setiap karya seni memang selalu memiliki keindahan / estetika yang objektif maupun subjektif. Seni dan keindahan selalu saling berdampingan. Secara etimologi "keindahan" berasal dari bahasa bahasa Inggris "beautiful". Terdapat pula beberapa pengertian keindahan antara lain, dalam arti luas; dalam arti estetis murni; dan dalam arti terbatas. Pengertian keindahan yang seluasluasnya meliputi keindahan seni; keindahan alam; keindahan moral; dan keindahan intelektual. Sedangkan keindahan dalam arti estetika murni, menyangkut pengalaman estetis dari seseorang dalam hubungannya dengan segala sesuatu yang diserapnya. Begitu pula dengan keindahan dalam arti terbatas yang hanya menyangkut bendabenda yang diterima dengan penglihatan, yaitu berupa keindahan dari bentuk dan warna secara kasat mata.

Menurut para ahli, teori estetika memiliki banyak arti. Immanuel Kant, Leo Tolstoy, Aristoteles, Sulzer, Winchelma, Humo, Shaftesbury, Hemsterhuis, Santo, Agustinus, hingga Thomas Aquinas memiliki persepsi tentang estetika yang sangatlah beragam. Namun terdapat salah satu teori estetika yang sering dijadikan tolak ukur suatu karya seni di Indoneisa. Teori estetika tersebut berasal dari seorang Filsuf seni Amerika "Monroe Curtis Beardsley", dia lahir dan tumbuh besar di Brifgeport, Connecticut dan belajar di Akedemi Yale (B.A. 1936, Ph.D. 1939). Karyanya dalam estetika yang terbaik dikenal untuk lebih mendukung atas teori instrumentalis seni dan konsep pengalaman estetis.

Monroe menjelaskan bahwa terdapat tiga ciri yang menjadi sifat-sifat 
keindahan dari benda-benda estetis pada umumnya. Ketiga ciri itu antara lain, unity, complexity dan intensity. Unity (kesatuan) berarti bahwa benda estetis ini tersusun secara baik atau sempurna dalam hal bentuk. Complexity (kerumitan), benda estetis atau karya seni yang bersangkutan tidak sederhana sekali, melainkan kaya akan isi maupun unsur-unsur yang saling berlawanan atau mengandung perbedaan-perbedaan halus. Intensity (kesungguhan), benda estetis yang baik harus mempunyai suatu kualitas tertentu yang menonjol dan bukan sekedar sesuatu yang kosong. Tak menjadi soal kualitas apa yang dikandungnya (misalnya suasana suram atau gembira, sifat lembut atau kasar), asalkan merupakan sesuatu yang intensif atau sungguh-sungguh.

Maka dari itu, penelitian ini lebih berfokus pada teori estetika yang dipaparkan oleh Monroe C. Berdsley. Dengan menggunakan teori estetika ini, peneliti dapat mengupas estetika dalam bentuk karya sastra Sestina secara umum.

\section{Metode Penelitian}

Penelitian ini bersifat deskriptif dengan Studi kepustakaan. Studi kepustakaan adalah suatu studi yang memperoleh atau mengumpulkan data dari berbagai sumber yang telah ada (peneliti sebagai tenaga kedua). Data dapat diperoleh dari berbagai sumber seperti Metode library research (penelitian kepustakaan), penelitian terapan ini tidak dilepaskan dari teoriteori terutama pada landasan berfikir (kerangka teori). Untuk keperluan ini, diperlukan berbagai literatur yang mengharuskan dilakukannya studi pustaka, apalagi pada penelitian yang bersifat kualitatif, maka penggunaan literature cukup dominan.

Untuk menganalisis data, teknik yang digunakan dapat diperoleh berdasarkan kemungkinan adanya penarikan kesimpulan dan pengambilan tindakan yang bersifat naratif yaitu dengan menarik kesimpulan/verifikasi dengan melakukan pengorganisasian untuk membentuk mana data yang relevan dengan tujuan penulisan dan mana yang tidak.

\section{Pembahasan}

Isi yang terdapat pada puisi Sestina, selalu bisa memberikan hal yang estetik. Seperti yang dikatakan oleh Margaret Spanos bahwa kumpulan tingkat intensitas dan resolusi yang sesuai diciptakan dari sebuah bentuk struktural, termasuk: intensitas struktural, semantik, dan estetika. Dia juga percaya bahwa ketegangan estetika, yang dihasilkan dari "konsepsi kelengkapan dan kesempurnaan matematisnya", yang bertentangan dengan "pengalaman kompleksitas labirinnya" dapat diselesaikan dengan memahami "keselarasan keseluruhan".

Bentuk sestina membutuhkan kepatuhan pada perintahnya yang sewenang-wenang dan ketat. Meskipun ini adalah bentuk bait yang kompleks, ia mencapai efek luar biasa karena pengulangan kata-kata yang rumit, yang disebut "pengulangan leksikal." Oleh karena itu, tidak bergantung pada pengukur atau rima saja. Terlepas dari menarik perhatian pada strukturnya, pengulangan leksikal ini menciptakan irama dalam puisi, membawa harmoni di antara berbagai bait, meningkatkan materi, membuat gagasan itu tetap hidup di benak pembaca, dan melibatkannya. Oleh karena itu, fungsi dasar sestina adalah untuk memfokuskan ide. 
Daya tarik puisi ini terletak pada kenyataan bahwa kata-kata kunci dan frasa tertentu diulang dalam setiap bait, yang membantu membangun gambaran ganda. Pilihan penyair dari sestina memungkinkan efek kaskade ini berlangsung secara logis dan berurutan. Penekanannya adalah pada perubahan posisi kata-kata akhir, sama seperti orang-orang yang berbeda dalam suatu tarian, pola berulang dari sifat yang telah ditentukan sebelumnya.

Stephanie Burt mencatat bahwa, "Sestina telah melayani, secara historis, sebagai keluhan", tuntutannya yang keras bertindak sebagai "tanda-tanda kekurangan atau paksaan". Struktur dapat meningkatkan subjek yang ia pesan; mengacu pada Elizabeth Bishop, A Miracle for Breakfast, David Caplan menunjukkan bahwa bentuk "tuntutan yang sewenang-wenang menggemakan subjeknya". Namun demikian, struktur formulir telah dikritik; Paul Fussell menganggap sestina sebagai "ekspresi struktural yang meragukan" ketika disusun dalam bahasa Inggris dan, terlepas dari bagaimana sestina itu digunakan dalam bahasa Inggris dan, terlepas dari bagaimana sestina itu digunakan, "tampaknya menjadi [suatu bentuk] yang memberi lebih banyak kesenangan struktural kepada sang penemu daripada kepada pembaca."

Seperti karya yang dipublikasikan oleh Elizabeth Bishop Pada tahun 1965 yang berjudul "Sestina". Puisi ini merefleksikan peristiwa yang sungguh-sungguh terjadi dalam kehidupannya. Ayahnya yang meninggal ketika dia masih berusia di bawah 2 tahun dan ibunya yang tidak pernah pulih dari gangguan saraf. Saat ia berusia 16 tahun, ia terpaksa tinggal dengan kerabat yang lebih tua. Beberapa tema yang akan dibahas antara lain, hubungan keluarga, keluarga disfungsional, pelarian $\mathrm{dr}$ kenyataan, terapi seni, dan subjek tabu. Sifat siklis sestina memungkinkan urutan berulang untuk mendapatkan kekuatan dan minat. Setiap bait adalah variasi pada tema - perubahan halus dalam bentuk dan meter menggabungkan secara dinamis dengan sintaks dan makna.

Sestina

September rain falls on the house.

In the failing light, the old grandmother sits in the kitchen with the child beside the Little Marvel Stove, reading the jokes from the almanac, laughing and talking to hide her tears.

She thinks that her equinoctial tears and the rain that beats on the roof of the house were both foretold by the almanac, but only known to a grandmother. The iron kettle sings on the stove. She cuts some bread and says to the child,

It's time for tea now; but the child is watching the teakettle's small hard tears

dance like mad on the hot black stove, the way the rain must dance on the house.

Tidying up, the old grandmother hangs up the clever almanac

on its string. Birdlike, the almanac hovers half open above the child, hovers above the old grandmother and her teacup full of dark brown tears. She shivers and says she thinks the house

feels chilly, and puts more wood in the stove.

It was to be, says the Marvel Stove.

I know what I know, says the almanac.

With crayons the child draws a rigid house

and a winding pathway. Then the child puts in a man with buttons like tears and shows it proudly to the grandmother. 
But secretly, while the grandmother busies herself about the stove, the little moons fall down like tears from between the pages of the almanac into the flower bed the child has carefully placed in the front of the house.

Time to plant tears, says the almanac. The grandmother sings to the marvelous stove

and the child draws another inscrutable house.

Kata complexity yang terdapat dalam teori estetika Monroe menjelaskan bahwa kerumitan adalah salah satu poin penting. Pertama, hal itu dapat terlihat jelas pada penyusunan sistem algoritma yang disuguhkan oleh salah satu contoh sestina karya Elizabeth Bishop ini. Pengacakan kata akhir pada setiap kalimat memberikan kesan rumit dan sulit dimengerti bagi orang awam yang pertama kali melihatnya tetapi juga memberikan kesan menakjubkan karena dapat membuat kalimat yang berbeda dan saling berkaitan pada setiap alinea dengan kata akhir yang sama. Terdapat enam kata pada setiap akhir kalimat yang menjadi poin penting dalam bermulanya algoritma Sestina. House, grandmother, child, stove, almanac dan tears adalah kata-kata yang tersusun vertikal pada stanza pertama, kemudian terjadi perubahan susunan pada stanza kedua menjadi : tears, house, almanac, grandmother, stove dan child. Kata house pada stanza pertama yang berada pada akhir kalimat pertama, berganti posisi pada akhir kalimat kedua pada stanza kedua. Begitupun dengan lima kata yang lain. Mereka menggunakan teknik yang sama untuk berpindah pada stanza berikutnya. Dalam jenis karya puisi ini, hanya enam kata yang telah dipilih menjadi poin penting dalam pembuatan suatu karya sestina. Kedua, dalam sebuah karya sestina, setiap stanza tidak boleh memiliki kalimat yang serupa dari stanza sebelumnya. Hal ini juga memberikan suatu unsur kompleksitas pada puisi jenis ini, karena membuat penulis harus memikirkan ulang kata dan kalimat yang berbeda untuk mengisi kekosongan dalam setiap makna untuk menimbulkan pusaran keidealan.

Selanjutnya adalah suatu kata yang menunjukkan kesatuan. Kesatuan yang dijelaskan oleh teori estetika Monroe adalah Unity. Di dalam sestina, poin unity terdapat dalam kaitan antar kalimat yang satu dengan kalimat yang selanjutnya begitu pula dengan kaitan antar masing-masing stanza. Hal ini membuat, suatu pemandangan yang membuat keunikan dari karya seni ini. Selain itu, kesatuan yang tercipta pada karya sestina ini juga tersurat di keanekaragaman pengambilan kata pada setiap kalimatnya.

Intensity adalah suatu kesungguhan atau suatu penekanan yang menjadi poin ketiga dalam teori estetika dari Monroe C. Berdsley. Suatu intensitas yang terkandung di dalam karya sestina dapat dilihat pada repetisi kata pada setiap akhir kalimat. Enam kata pokok yang dijadikan poin, adalah suatu intensitas yang berkelanjutan. Di setiap stanza memberikan tekanan yang pada akhir kalimat bahwa telah terjadi repetisi yang terpola. Algoritma yang terdapat pada sestina membuat hal tersebut menjadi hal yang mungkin. Pengulangan leksikal yang terus menerus diterapkan pada setiap stanza menyebabkan suatu penekanan terhadap ke enam kata penting tersebut.

\section{Penutup}

Suatu karya musik atau lagu biasanya memiliki lirik yang kuat untuk memberikan pengaruh terhadap audiens. Fungsi lirik menjadi hal yang sangat penting untuk berkembangnya karya seni tersebut. lirik yang biasanya diambil dari suatu puisi-puisi juga memiliki tingkat emosional yang memadai. Salah satunya adalah Sestina, suatu karya puisi yang dapat juga dijadikan 
sebuah lirik lagu. Sestina adalah karya puisi yang lahir pada abad 12 di perancis dan termasuk salah satu karya puisi yang tidak berima.

Dalam penelitian ini, telah dapat disimpulkan setiap karya seni memiliki nilai keindahan yang menarik tergantung dilihat dari sudut pandang tertentu. Pengkajian sestina dalam sudut pandang teori estetika Monroe C. Berdsley telah menghasilkan tiga poin penting. Unity, complexity, dan intensity adalah poin penting dalam teori estetika yang dikemukakan oleh Monroe C. Berdsley. Ketiga aspek itu, saling berkaitan satu sama lain untuk membentuk suatu nilai keindahan pada karya seni.

Pada sestina, complexity terdapat pada pembuatan sistem algoritmanya. Sistem algoritma tersebut juga dikenal sebagai circular of sestina. Intensity dalam karya ini merujuk kepada pengulangan kata atau repetisi yang digunakan pada keenam kata penting untuk dijadikan dasar pembuatan sestina. kata-kata tersebut adalah kata akhir pada setiap kalimat yang dilakukan pengulangan pada setiap stanzanya. Dan yang terakhir, unity pada karya ini dapat dilihat pada kaitan antar kalimat dari kalimat satu dengan kalimat lainnya serta stanza satu dengan stanza lainnya. Selain itu, kesatuan atau unity yang tercipta pada karya sestina ini juga tersurat di keanekaragaman pengambilan kata pada setiap kalimatnya

\section{Referensi}

Antine, Sarah \& Terry Hauptman (2011). Poetry: Music, Patience and Form. Bridges, Vol. 16, No. 1 (Spring), pp. 77-85,

http://www.jstor.org/stable/10.2979/ bridges.16.1.77

Burt, Stephen (2007). Sestina! or, The Fate of the Idea of Form. Modern Philology. 105 (1): 218-241. https://dash.harvard.edu/bitstream/
handle/1/3426325/Burt_Sestina.pdf? sequence $=2$

Caplan, David (2006). Questions of possibility: contemporary poetry and poetic form. Oxford University Press, US.

Djelantik, A.A.M. 1990. Pengantar Dasar Ilmu Estetika Jilid I : Estetika Instrumental. Denpasar : Sekolah Tinggi Seni Indonesia.

. 1992. Pengantar Dasar Ilmu

Estetika Jilid II : Falsafah Keindahan dan Kesenian. Denpasar : Sekolah Tinggi Seni Indonesia.

Fussell, Paul (1979). Poetic Meter and Poetic Form. McGraw-Hill Higher Education, US.

Gie, The Liang. 1996. Filsafat Keindahan. Yogyakarta: Pusat Belajar Ilmu Berguna (PUBIB)

Goody, Jack (1987). The Interface Between the Written and the Oral. Cambridge University Press, UK.

Kartika, Dharsono Sony. 2007. Estetika. Bandung: Rekayasa Sains

Mundy, John Hine (1973). Europe in the high Middle Ages, 1150-1309. Basic Books, New York.

Preminger, Alex, T.V.F. Brogan, Frank J. Warnke, O.B. Hardison, Jr., \& Earl Miner (1993). The New Princeton Encyclopedia of Poetry and Poetics. Princeton University Press, US.

Spanos, Margaret (1978). "The Sestina: An Exploration of the Dynamics of Poetic Structure". Medieval Academy of America. 53 (3): 545557.

https://www.journals.uchicago.edu/ doi/10.2307/2855144

Strachan, John R \& Richard Terry (2000). Poetry: an introduction. Edinburgh University Press, UK. 